\title{
Estimasi Dana Masyarakat melalui Valuasi Ekonomi Kerusakan Terumbu Karang di Desa Poka Kota Ambon
}

\author{
Eygner Gerald Talakua1, Renoldy Lamberthy Papilaya1, dan Irchan Sahdian \\ Wailissa $^{1}$
}

1Program Studi Agrobisnis Perikanan, Fakultas Perikanan dan Ilmu Kelautan, Universitas Pattimura. Kampus Poka, Kota Ambon, Telp. (0911) 3825060; e-mail: eygnertalakua@gmail.com

\begin{abstract}
ABSTRAK
Teluk Ambon, Kota Ambon merupakan kawasan dengan tekanan antrophogenik tinggi dan sangat berpengaruh pada sumber daya pesisir dan laut khususnya terumbu karang. Kerusakan terumbu karang di Teluk Ambon terjadi di Desa Poka, penanganannya telah dilakukan melalui program rehabilitasi dengan teknik transplantasi karang, namun perlu adanya dukungan dan peran serta masyarakat dalam pengelolaannya. Salah satu faktor belum berhasilnya pengelolaan terumbu karang adalah kurangnya pengalokasian dana, padahal sesuai aturan dana kegiatan pengelolaan terumbu karang salah satunya dapat bersumber dari masyarakat. Penelitian ini bertujuan untuk mengetahui persepsi masyarakat terhadap keberadaan terumbu karang, menganalisis nilai ekonomi kerusakan terumbu karang, dan mengestimasi dana masyarakat guna perbaikan kerusakan terumbu karang di Desa Poka, Kota Ambon. Penelitian dilakukan pada bulan Januari hingga Mei 2018 menggunakan metode studi kasus. Sampel penelitian sebanyak 107 kepala keluarga diperoleh melalui proposive sampling dan teknik pengembilan sampel sosial ekonomi. Analisis data terdiri dari analisis persepsi masyarakat menggunakan skala likret pada tiga indikator: pengetahuan, manfaat, dan kerusakan terumbu karang; analisis valuasi ekonomi non-market melalui metode CVM; dan estimasi dana masyarakat melalui kalkulasi nilai total willingness to pay berdasarkan jumlah masyarakat yang bersedia. Hasil penelitian menunjukkan bahwa persepsi sebagian besar masyarakat di Desa Poka adalah sangat tahu dan tahu keberadaan terumbu karang. Persepsi ini berhubungan dengan keinginan membayar masyarakat untuk perbaikan kerusakan terumbu karang, dimana nilai ekonomi kerusakan terumbu karang di Desa Poka adalah Rp. 4.288.000/bulan atau Rp 51.456.000/tahun. Dari nilai ekonomi ini diperoleh estimasi dana masyarakat untuk perbaikan kerusakan terumbu karang sebesar Rp 3.888.322,95/bulan atau Rp 46.659.875,46/tahun.
\end{abstract}

Kata kunci: Dana, Masyarakat, Nilai ekonomi, Terumbu karang, Desa Poka

\begin{abstract}
Ambon Bay, Ambon City is a region with high anthropogenic pressure and is very influential on coastal and marine resources, especially coral reefs. Damage to coral reefs in Ambon Bay occurred in Poka Village, handling has been done through the rehabilitation program with coral transplantation techniques, but the need for support and community participation in its management. One of the factors not yet successful management of coral reefs is lack of funds, whereas according to the rules of fund of coral reef management activities one of them can be sourced from the community. This study aims to determine the perception of the community on the existence of coral reefs, analyze the economic value of coral reef damage, and estimate communityfunds to repair damage to coral reefs in Poka Village, Ambon City. The study was conducted from January to May 2018 using case study method. A sample of 107 heads of households was obtained through proposive sampling and techniques of economical sampling of economies. The data analysis consisted of the analysis of community perception using the likeness scale on three indicators: knowledge, benefit, and coral reef damage; analysis of non-market economic valuation through CVM method; and estimates of communityfunds through the calculation of the total value of willingness to pay based on the number of people who are willing. The results of the study show the fact that most of the people in Poka Village know very well and know about coral reefs. This perception is related to the community's need to improve damage to coral reefs, while the economic value of damage to coral reefs in Poka Village is Rp. 4,288,000/month or Rp. 51,456,000/year. From this economic value, an estimation of public funds is obtained to repair damage to coral reefs of Rp. 3,888,322.95/month or Rp. 46,659,875.46/year.
\end{abstract}

Keywords: Funds, Community, Economic value, Coral reef, Desa Poka.

Cara sitasi:Talakua, G., E., Papilaya, L., R., dan Wailissa, S., I., 2018. Estimasi Dana Masyakarat Melalui Valuasi Ekonomi Kerusakan Terumbu Karang Di Desa Poka Kota Ambon. Jurnal Ilmu Lingkungan, 17(1), 42-50, doi:10.14710/jil.17.1.42-50.

\section{Pendahuluan}


Maluku tercakup dalam kawasan segitiga karang dunia (coral triangle). Coral triangle adalah kawasan perairan seluas 5,7 juta ha yang berbentuk segitiga meliputi sebagian besar wilayah perairan Indonesia (bagian tengah dan timur), Malaysia, Papua New Guinea, Philipina, Kepulauan Salomon dan Timor Leste (Ralahalu, 2012). Di Indonesia, Maluku dikenal sebagai salah suatu wilayah diantara empat wilayah lain (Sulawesi, Bagian Barat Papua dan Nusatenggara) yang memiliki sebaran karang tertinggi di bagian tengah Indonesia dan Indonesia Timur (Giyanto $d k k, 2017$ ).

Terumbu karang memiliki nilai dan arti penting ditinju dari sisi sosial, ekonomi dan budaya karena hampir sepertiga penduduk Indonesia bermukim di wilayah pesisir dan menggantungkan hidupnya pada perikanan laut dangkal. Masyarakat masih menggunakan caracara tradisional dan terbatas di perairan pesisir yang relatif dangkal, termasuk terumbu karang untuk pemanfaatan sumberdaya perikanannya (Sahetapy $d k k, 2017) . M e s k i p u n$ memiliki nilai ekonomi yang tinggi, sayangnya, terumbu karang sangat rentan terhadap kerusakan, terutama oleh tekanan manusia (Giyanto $d k k, 2017$ ).

Kerusakan terumbu karang di Maluku terjadi di perairan pesisir Teluk Ambon. Teluk Ambon merupakan kawasan yang mempunyai tekanan antropogenik tinggi dan sangat berpengaruh terhadap ekosistem terumbu karang. Lebih jauh Indrabudi dan Alik (2017)mengungkapkan bahwa, kondisi karang di Teluk Ambon tahun 2015 berada dalam kategori "sedang" (rata-rata karang hidup 31,43\%). Jika dibandingkan dengan tahun 2012 (rata-rata karang hidup 39,06\%) telah terjadi penurunan persentase karang hidup dan terjadi di lima stasiun (St). Salah satu stasiun yang berada dalam kategori buruk (persen penutupan karang batu antara 0 dan 24,9\%) bahkan bisa dikatakan hampir hilang dimana persentase tutupan karang sangat kecil adalah StPoka pada titik koordinat $3^{0} 39^{\prime} 37.90^{\prime \prime}$ dan $128^{0} 11^{\prime} 50.20^{\prime \prime} E$ di Desa Poka. Persentase tutupan bentos di St. Poka terdiri atas karang hidup yang berasal dari jenis NonAcropora yang terdiri atas kelompok Massive Corals (CM) 9,4\%, Encrusting Corals (CE) 0,9\% Submassive Corals (CS) 0,6\%, dan Mushroom Corals (CMR) 0,2 serta Dead Coral with Algae persentasenya $52 \%$. Komponen abiotik yang ditemukan sepanjang garis transek, yaitu sand(S) 0,9\% dan silt (Sl) 36\%.

Degradasi terumbu karang di Desa Poka disebabkan oleh semakin meningkatnya sedimentasi yang diakibatkan oleh run off pada saat musim hujan, sementara sirkulasi massa air di Teluk Ambon Dalam (TAD) sangat kecil. Curah hujan yang tinggi dan aliran material permukaan dari daratan (mainland run off) dapat membunuh terumbu karang melalui peningkatan sedimen dan terjadinya penurunan salinitas air laut. Efek selanjutnya adalah kelebihan zat hara (nutrient overload) yang berkontribusi terhadap degradasi terumbu karang melalui peningkatan pertumbuhan makroalga yang melimpah (overgrowth) terhadap karang. Kerusakan terumbu karang di Desa Poka juga diakibatkan oleh material pembangunan jembatan merah putih yang masuk ke dalam air laut menyebabkan peningkatan turbiditas (Indrabudi dan Alik, 2017).

Upaya penanganan kerusakan terumbu karang di Desa Poka telah dilakukan melalui program rehabilitasi di Teluk Ambon termasuk perairan pesisir Desa Poka (Tanjung Tiram) telah dilakukanmelalui teknik transplantasi karang (Pelasula, 2017). Rekomendasi diberikan adalah diperlukan revitalisasi peraturan yang ada dan konsistensi dalam penerapan, pemantauan dan pengendalian, serta perlu adanya peran serta masyarakat pesisir di dekat lokasi transplatasi karang.Terkait dengan peran serta masyarakat, dalam Peraturan Daerah Provinsi Maluku Nomor 10 Tahun 2014 tentang Pengelolaan Ekosistem Terumbu Karang pada pasal 11 hingga 13 telah memuat hak dan kewajiban masyarakat, kerjasama, dan pendanaan pengelolaan ekosistem terumbu karang di Provinsi Maluku (PPM, 2014). Terkait aspek pendanaan, COREMAP (2001) mengungkapkan bahwa salah satu faktor belum berhasilnya pengelolaan terumbu karang di Indonesia adalah kurangnya pengalokasian danabagi pengelolaan terumbu karang. Sedangkan terkait aspek peran masyarakat, penelitian yang dilakukan Hiariey (2013)terhadap masyarakat yang tinggal di kawasan TAD menunjukkan bahwa tingkat peran serta masyarakat sebagai pemanfaatan pesisir (termasuk di dalamnya terumbu karang) dalam pengelolaan wilayah pesisir TAD tergolong sedang dan rendah, dan faktor yang sangat mempengaruhi peran serta masyarakat pemanfaatan pesisir dalam pengelolaan wilayah pesisir TAD adalah persepsi.

Selain program rehabilitasi, salah satu aspek yang penting dalam pengelolaan terumbu karang di Desa Poka adalah penilaian ekonomi kerusakan terumbu karang. Menurut Adrianto (2004), kelestarian ekosistem pesisir dan laut (termasuk terumbu karang) menjadi sangat penting guna menjamin keberlanjutan, sehingga dinamika ekosistem harus dimasukan dalam pertimbangan pengelolaan termasuk pentingnya mengetahui nilai ekonomi sumber daya sebagai salah satu faktor input kebijakan. Salah satu contoh kasus berkaitan dengan input kebijakan adalah penggunaan teknik contingent valuation method (CVM) dalam perhitungan kerugian ekonomi nilai non-guna akibat pencemaran laut oleh Exxon Valdez yang merupakan salah satu kasus pencemaran laut terbesar di Amerika 
Serikat (Carson $d k k$, 2003). Dalam CVM dikembangkan metode pembayaran melalui tarif masuk, pajak, penambahan harga barang dan jasa, atau juga secara sukarela (volountary) oleh masyarakat. Berhubungan dengan masalah penandaan dalam pengelolaan terumbu karang di Desa Poka, penggunaan teknik CVM dalam menjadi menarik untuk diteliti. Mengingat dalam aturan dana pengelolaan ekosistem terumbu karang dapat bersumber dari swadaya masyarakat.

Untuk membangun pemahaman hingga timbul peran atau partisipasi masyarakat untuk berswadaya dalam bentuk dana masyarakat bukanperkara mudah. Salah satu langkah awal yang dapat dilakukan adalah membangun persepsi masyarakat. Sehingga diharapkan persepsi masyarakat Desa Poka yang baik terhadap keberadaan terumbu karang akan mendorong masyarakat untuk berpartisipasi, bersedia dan sanggup menyisihkan pendapatannya (bersedia membayar) untuk perbaikan kerusakan terumbu karang di Desa Poka.Berdasarkan uraian tersebut, penelitian ini bertujuan untuk mengkaji persepsi masyarakat, menganalisis hubungan persepsi dan keinginan membayar masyarakat, menganalisis nilai ekonomi, dan mengestimasi dana masyarakat dalam kerusakan terumbu karang di Desa Poka, Kota Ambon.

\section{Metode Penelitian}

Penelitian ini menggunakan metode kombinasi (mixed methods). Dalam Sugiyono (2011) mixed methods adalah suatu metodepenelitian yang mengkombinasikan atau menggabungkan antarametode kuantitatif dan metode kualitatif untuk digunakan secarabersama-sama dalam suatu kegiatan penelitian sehingga diperoleh datayang lebih komprehensif, valid, reliabel dan objektif. Kombinasi metode penelian yang diguanakan adalah metode studi kasus(bersifat kualitatif) dan metode survei (bersifat kuantitatif). Menurut Nazir (2014) studi kasus adalah metode untuk menghimpun dan menganalisis data berkenaan dengan studi kasus.Kemudian dilakukan survei, menurut Sugiyono (2011) metode survei adalah metodepenelitian yang dilakukan pada populasi besar maupun kecil, tetapi datayang dipelajari adalah data dari sampel yang diambil dari populasitersebut, sehingga ditemukan kejadiankejadian relative, distribusi, danhubunganhubungan antar variabel, sosiologis maupun psikologis.

\subsection{Metode Pengumpulan Data}

Data yang digunakan dalam penelitian ini adalah data primer dan data sekunder. Data primer merupakan data yang diperoleh dari pihak pertama melalui wawancara terarah (guided interview) secara langsung dengan 107 kepala keluarga sebagai responden. Wawancara terarah (guided interview) dimana peneliti menanyakan kepada subjek yang diteliti beerupa pertanyaan yang menggunakan pedoman (kuesioner) yang disipakan sebelumnya (Sujarweni, 2015). Data sekunder di peroleh dari instansi terkait dan berbagai sumber-sumber pustaka. Pengumpulan data sekunder berupa data tercatat yang diperoleh dari kantor Desa Poka dan Lembaga Ilmu Pengetahuan Indonesia (LIPI) yang berkaitan dengan penelitian ini. Selain itu terdapat data sekunder diperoleh dari publikasi tulisan ilmiah penelitian.

\subsection{Metode Pengambilan Sampel}

Populasi dalam penelitian ini adalah kepala keluarga (KK) penduduk Desa Poka di rukun warga (RW) 001 dan 002 (dari 6 RW di Desa Poka) masing-masing berjumlah $328 \mathrm{KK}$ dan $208 \mathrm{KK}$ atau total $536 \mathrm{KK}$. Jumlah RW dan KK ini telah mewakili penduduk Desa Poka yang bermukim dekat perairan laut Teluk Ambon Dalam (TAD) atau dekat lokasi kerusakan terumbu karang di Desa Poka.

Metode pengambilan sampel dalam penelitian ini adalah metode purposive sampling (Sugiyono, 2015). Pertimbangan sampel adalah penduduk bermata pencahian sebagai nelayan ataupun penduduk umum pada RW001 dan RW002 di Desa Poka.Jumlah sampel diambil dari kelompok responden pertama dan ke dua dengan menggunakan teknik pengambilan sampel penelitian sosial ekonomi yang dikembangkan oleh Fauzi (2001) yaitu:

$\mathrm{n}=\frac{\mathrm{NZ}^{2} \times 0,25}{\left(\mathrm{~d}^{2} \times(\mathrm{N}-1)\right)+\left(\mathrm{Z}^{2} \times(0,25)\right)}$

Dimana:

$\mathrm{n}=$ Jumlah sampel yang diambil

$\mathrm{N}=$ Jumlah populasi (yang diketahui dan diperkirakan)

$\mathrm{Z}=$ Standar deviasi yang berhubungan dengan tingkat kepercayaan (lihat tabel $\mathrm{z}$ statistik/distribusi z satu arah dengan $\alpha=$ 0,05 atau $(95 \%)$ adalah 1,645)

$\mathrm{d}=$ Tingkat akurasi/persis (digunakan nilai 0,1 atau $10 \%)$

Jumlah penduduk RW 001 dan RW 002

yang berada di Desa Poka adalah 328 KK dan 208

KK sehingga berdasarkan rumus di atas didapatkan jumlah sampel sebesar:

$\mathrm{n}_{\mathrm{rw} 1}=$

$\frac{(328) \times(1,645)^{2} \times(0,25)}{(0,1)^{2} \times(328-1)+\left((1,645)^{2} \times 0,25\right)}=56,23=56$

$\mathrm{n}_{\mathrm{rw} 2}=$

$\frac{(308) \times(1,645)^{2} \times(0,25)}{(0,1)^{2} \times(308-1)+\left((1,645)^{2} \times 0,25\right)}=51,23=51$

$$
\mathrm{n}=56+51=107
$$


Total sampel dalam penelitian ini adalah sebanyak $107 \mathrm{KK}$ sebagai responden, terbagi atas RW001 sebanyak 56 responden dan RW002 sebanyak 51 responden.

\subsection{Metode Analisis Data}

Metode analisis data digunakan adalah metode deskriptif kualitatif dan kuantitatif. Metode deskripsi kualitatif untuk mendeskripsikan arakteristik responden dan gambaran umum lokasi, sedangkan metode deskripsi kuantitatif dijabarkan sebagi berikut:

1) Analisis persepsi masyarakat.

Untuk mengukur persepsi masyarakat terhadap terumbu karang di Desa Poka digunakanskala likert (Sugiyono, 2010). Dengan skala likert, variabel yang akan diukur (persepsi masyarakat) dijabarkan menjadi indikator variabel (pengetahun tentang terumbu karang, manfaat terumbu karang, kerusakan terumbu karang). Indikator tersebut dijadikan titik tolak untuk menyusun pertanyaan atau pernyataan yang diberi skor5 (sangat tahu), 4 (tahu), 3 (ragu-ragu), 2 (tidak tahu), dan 1 (sangattidak tahu).

Setelah dilakukan pengukuran dengan skala likert (diberikan skor), dilakukan tabulasi data atas tanggapan responden. Kemudian dilakukan perhitungan rata-rata secara horisontal (rata-rata masing-masing skor responden) dan secara vertikal (rata-rata masing-masing pertanyaan atau indikator variabel). Nilai total rata-rata kemudian dicocokan dengan nilai interval skor penelitian untuk memperoleh kategori tingkat persepsi masyarakat (responden) di Desa Poka terhadap terumbu karang. Nilai interval skor penelitian (Tabel 1) ditentukan dengan persamaan (Akdon dan Riduwan, 2013):

$\mathrm{P}=$ Rentang/Banyak kelas interval

Dimana:

$\mathrm{P}=$ Panjang kelas interval

Rentang $=$ Skor tertinggi dikurangi skor terendah

Diperoleh: $P=(5-1) / 4=4 / 5=0,8$. Sehingga diperoleh nilai interval dan kategori variabel persepsi.

Tabel 1. Interval dan Kategori Variabel Penelitian

\begin{tabular}{cc}
\hline \hline Interval & Kategori Persepsi \\
\hline $1,00-1,80$ & Sangat tidak tahu (STT) \\
$1,81-2,60$ & Tidak tahu (TT) \\
$2,61-3,40$ & Ragu-ragu (RR) \\
$3,41-4,20$ & Tahu (T) \\
$4,21-5,00$ & Sangat tahu (ST) \\
\hline
\end{tabular}

2) Analisis Hubungan Persepsi dan WTP

Analisis hubungan persepsi dan kesedian membayar masyarakat (willingness to pay atau WTP) guna perbaikan kerusakan terumbu karang di Desa Poka menggunakan persamaan chi-square $\left(\mathrm{X}^{2}\right)$ tes median extension untuk menguji hipotesis komparatif media $\mathrm{k}$ sampel independen dengan data berbentuk ordinal (Sugiyono, 2015), yakni:

$X^{2}=\sum \frac{\left(f o_{i j}-f h_{i j}\right)^{2}}{f h_{i j}}$

Dimana:

$X^{2}=$ Nilai chi-square hitung

$f_{i j}=$ Banyak kasus pada basri ke i dan kolom ke j

$f h_{i j}=$ Banyak kasus yang diharapkan pada baris ke i dan kolom ke $\mathrm{j}$

$\Sigma$ = Penjumlahan semua sel

Dengan variabel independen adalah persepsi dan variabel dependen adalah kesedian membayar masyarakat, dan hipotesisnya:

$\mathrm{H}_{0}=$ tidak terdapat hubungan persepsi dan kesediaan membayar masyarakat.

$\mathrm{H}_{1}=$ terdapat hubungan persepsi dan kesediaan membayar masyarakat.

Kriteria pengujian, menerima $\mathrm{H}_{0}$ jika nilai $\mathrm{X}^{2}$ hitung < nilai $\mathrm{X}^{2}$ tabel. Penilaian $\mathrm{X}^{2}$ tabel $=\mathrm{k}-$ 1 dan $\alpha$ ditetapkan 0,05 ( $\mathrm{k}$ adalah banyaknya ketegori dalam sampel).

3) Analisis Valuasi Ekonomi Non-Market

Analisis valuasi ekonomi non-market terumbu karang di Desa Poka menggunakan teknik valuasi non-market langsung (survei) atau expressedwillingness to pay(WTP) dan metode valuasi kontingensi atau contingen valuation method (Fauzi, 2014). Tiga tahapan utama sesuai metode CVM dalam penelitian ini adalah:

a. Identifikasi barang dan jasa yang akan divaluasi, barang dan jasa yang akan divaluasi adalah terumbu karang di perairan laut Desa Poka.

b. Konstruksi skenario hipotetik

Kondisi terumbu karang di Desa Poka yang dijadikan baseline adalah hasil penelitian yang dikemukakan oleh Indrabudi dan Alik (2017), target yang ingin dicapai adalah kondisi terumbu karang pulih menjadi lebih baik.Kebijakan yang diharapkan tertuju pada adanya pajak atau dana yang bersedia dibayar oleh masyarakat dan dikelola oleh lembaga masyarakat, pemerintah desa atau pemerintah Kota Ambon guna perbaikan kerusakan terumbu karang di Desa Poka.

c. Elisitasi nilai moneter

Metode elisitasi adalah teknik mengekstrak informasi kesanggupan membayar dari responden dengan menanyakan besaran pembayaran melalui format single bounded dichotomousdengan 4 kategori bid. Kategori bid tersebut adalah:

1. Kategori kelas Rp 2.000,-/bulan

2. Kategori kelas Rp 5.000,-/bulan

3. Kategori kelas Rp 7.500,-/bulan 
4. Kategori kelas Rp 10.000,-/bulan Nilai bid atau tawaran ini disesuaikan dengan retribusi pelayanan persampahan/kebersihan di Kota Ambon sebesar Rp 6.000,-/bulan untuk objek retribusi perumahan dan $\mathrm{Rp} 2.000,-/$ bulan untuk kos-kosan (PKA, 2013).

Untuk mendapatkan nilai WTP dilakukan perhitungan dengan menggunakan metode non parametrik atau metode TurnbulldanKaplan-Mair-Trunbull (KMT).

a. Metode Turnbull, rataan WTP dapat dihitung menggunakan formula:

$$
\begin{aligned}
& E(W T P)=\sum_{j=0}^{M} B_{j}\left(F_{j+1}-F_{j}\right) \\
& E(W T P)=\sum_{j=0}^{M} B_{j} f_{j+1}^{*}
\end{aligned}
$$

Dimana:

$E(W T P)=$ Nilai rataan $W T P(\mathrm{Rp} /$ bulan $)$

$B_{j} \quad=$ Nilai lelang ke $\mathrm{j}$

Fj = Distribusi responden yang menjawab "tidak" pada lelang ke j

$f_{j}^{*} \quad=F_{j+1}-F_{j}$

Untuk nilai lelang $\mathrm{j}=\mathrm{Rp} 0,-, \mathrm{Rp} 2.000,-$, Rp 5.000,-, Rp 7.500,-, hingga ke $M=R p$ 10.000,-.

b. Metode K-M-T, rataan WTP dapat dihitung menggunakan formula:

$$
E_{K M T}(W T P)=\sum_{j=1}^{M} B_{j}\left(F_{j}-F_{j+1}\right)
$$

Dimana:

$$
\begin{aligned}
E_{\text {Кмт }}(W T P)= & \text { Nilai rataan WTP } \\
& \text { (Rp/bulan) } \\
B_{j} & =\text { Nilai lelang ke } \mathrm{j} \\
F j & = \\
& \text { Distribusi responden yang } \\
& \text { menjawab "ya" pada } \\
& \text { lelang ke } \mathrm{j}
\end{aligned}
$$

Untuk nilai lelang $\mathrm{j}=\mathrm{Rp} 2.000,-, \mathrm{Rp}$ $5.000,-$, Rp 7.500,-, hingga ke $M=R p$ $10.000,-$.

c. Validasi nilai $E W T P$

Haab dan McConnel (2002) dalam Fauzi (2014) merumuskan formula untuk menghitung keragaman (variance) yang dapat digunakan untuk menghitung seberapa besar tingkat kepercayaan terhadap pendugaan nilai EWTP. Keragaman dari batas bawah EWTP(monotonically increasing)adalah:

$$
\begin{aligned}
V\left(E_{L B}(W T P)=\right. & \sum_{j=0}^{M} \frac{F_{j}\left(1-F_{j}^{*}\right)}{T_{j}^{*}}\left(B_{j}\right. \\
& \left.-B_{j-1}\right)^{2}
\end{aligned}
$$

Dimana:

$$
\begin{aligned}
V & =\text { Keragaman } \\
E_{L B}(W T P)= & \text { Batas bawah nilai rata-rata } \\
& W T P
\end{aligned}
$$

$$
\begin{aligned}
B_{j} & = & \text { Nilai lelang ke } \mathrm{j} \\
F j & = & \text { Distribusi responden yang } \\
& & \text { menjawab "tidak" pada } \\
& & \text { lelang ke } \mathrm{j} \\
& = & F_{j+1}-F_{j} \\
F_{j}^{*} & = & \text { Total responden pada nilai } \\
T_{j}^{*} & & \text { lelang ke } \mathrm{j}
\end{aligned}
$$

Untuk nilai lelang $\mathrm{j}=\mathrm{Rp} 0,-, \mathrm{Rp} 2.000,-$, Rp 5.000,-, Rp 7.500,-, hingga ke M = Rp $10.000,-$.

d. Setelah didapatkan masing-masing dugaan nilai rataan WTP maka pendugaan total WTP dapat dihitung. Total WTP adalah dugaan rataan WTP dikalikan dengan jumlah kepala keluarga (KK), rumus total WTP yaitu:

$$
T(W T P)=E(W T P) \times \mathrm{N}
$$

Dimana:

$$
\begin{aligned}
& T(W T P)=\text { Total } W T P(\mathrm{Rp} / \text { bulan }) \\
& E(W T P)=\text { Rataan } W T P(\mathrm{Rp} / \text { bulan }) \\
& \mathrm{N}=\text { Kepala keluarga dalam populasi }
\end{aligned}
$$

Dengan demikian valuasi (nilai) ekonomi kerusakanterumbu karang di Desa Poka sama dengan nilai $T(W T P)$.

4) Estimasi Dana Masyarakat

Estimasi dana masyarakat bagi perbaikan kerusakan terumbu karang di Desa Poka, Kota Ambon diperoleh dari nilai total willingness to payT(WTP). Dengan mengkalkulasi nilai $T(W T P)$ dari jumlah responden yang bersedia membayar. Menurut Fauzi (2010), salah satu tujuan CVM pada hakekatnya adalah mengetahui keinginan membayar masyarakat $(W T P)$. Persamaan matematis estimasi adalah: $\mathrm{E}_{\mathrm{dm}}=E(W T P) \times \mathrm{N}(W T P)$

Dimana:

$\mathrm{E}_{\mathrm{dm}}=$ Estimasi danamasyarakat (Rp/bulan)

$E(W T P)=$ Rataan $W T P(\mathrm{Rp} / \mathrm{bulan})$

$\mathrm{N}(W T P)=$ Kepala keluarga dalam populasi yang bersedia membayar (KK).

\section{Hasil dan Pembahasan}

\subsection{Karakteristik Responden}

Karakteristik responden dimaksud merupakan karakteristik sosial ekonomi. Terdapat 7 indikator sosial ekonomi yakni jenis kelamin, umur, pendidikan, jumlah tanggungan keluarga, mata pencaharian, pendapatan dan status kependudukan yang dimiliki oleh responden.

Gambar 1 menunjukkan bahwa responden didominasi oleh laki-laki, berumur produktif, berpendidikan SMA, memiliki tanggungan $\leq 3$ orang, bermata pencaharian di luar bidang perikanan dan kelautan, berpendapatan di atas umpah minimum regional, dan sebagian besar merupakan penduduk asli Desa Poka. Berdasarkan karakteristik tersebut, 
responden dinilai mampu memberikan keterangan dan menjawab pertanyaan atau pernyataan dalam kuesioner penelitian yang bersifat terbuka, berformat skala likert dan single bounded dichotomous (referendum) dengan baik.

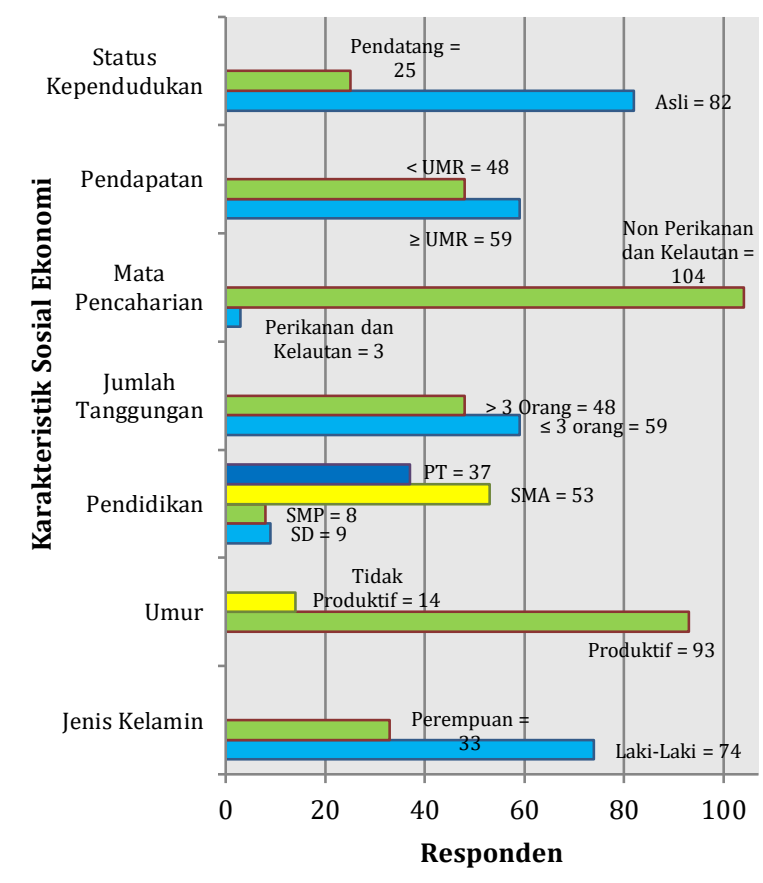

Gambar 1. Karakteristik Responden

\subsection{Terumbu Karang di Desa Poka}

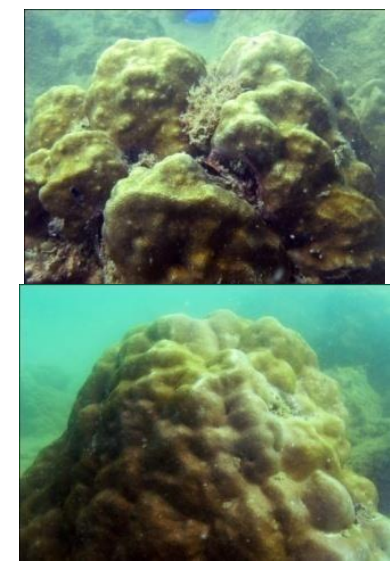

Sumber: LIPI, 2015

Gambar 2.Karang Jenis Porites lutea dan Porites lobata pada Perairan Desa Poka

Data kondisi terumbu karang di Desa Pokapada posisi $03^{\circ} 39^{\prime} 37,6^{\prime \prime}$ LS dan $128^{\circ} 11^{\prime}$ 50,2" BT menurut LIPI (2015) menunjukkan bahwa, persentase tutupankomponen karang hidup hanya11,10\%, dan berada pada kategori "sangat rusak",kesemuanya dari kelompok NonAcropora. Karang hidup non-Acropora yang mendominasi pertumbuhan karang hidup pada daerah ini yaitu dari bentuk pertumbuhannya Massive (CM) dengan persentase tutupan 8,73\%, dari jenis Porites lutea dan Porites lobata (Gambar 2). Pada stasiun ini komponen yang memiliki nilai persentase tutupan tertinggi adalah karang mati yang telah ditumbuhi Algae (DCA) dengan persentase tutupan 52,00\%, dan komponen pasir berlumpur (silt) dengan nilai $36,03 \%$. Bila dibandingkan dengan hasil monitoring sebelumnya pada tahun 2012 terjadi penurunan nilai persentase tutupan karang hidup cukup besar yaitu 37,28\%.

\subsection{Persepsi Masyarakat}

Persepsi masyarakat di Desa Poka, Kota Ambon terhadap keberadaan terumbu karang, terwakili oleh 107 responden kepala keluarga (KK). Berdasarkan 3 indikatorvariabel persepsi, yakni pengetahun tentang terumbu karang, manfaat terumbu karang, dan kerusakan terumbu karang yang kemudian dijabarkan dalam 15 pertanyaan/pernyataan.Distribusi responden berdasarkan persepsi pada Tabel 2 menunjukkansebagian besar responden $(67,29 \%)$ sangat tahu dan tahu tentang terumbu karang dan sebagian kecil responden (32,71\%) ragu-ragu dan tidak tahu tentang terumbu karang, dengan demikian sebagian besar persepsi masyarakat di Desa Poka adalah sangat tahu dan tahu, dan hanya sebagian kecil yang ragu-ragu dan tidak tahu.

Tabel 3. Distribusi Responden Berdasarkan Persepsi

\begin{tabular}{lrr}
\hline \hline \multicolumn{1}{c}{ Kategori Persepsi } & Jumlah Responden & $\begin{array}{c}\text { Persentase } \\
(\%)\end{array}$ \\
\hline Sangat tidak tahu & - & 0,00 \\
Tidak tahu & 11 & 10,28 \\
Ragu-ragu & 24 & 22,43 \\
Tahu & 50 & 46,73 \\
Sangat tahu & 22 & 20,56 \\
$\quad$ Jumlah & 107 & 100,00 \\
\hline
\end{tabular}

Persepsi responden yang sangat tahu dan tahu terungkap dari pengetahuan tentang arti terumbu karang, keberadaan terumbu karang di Desa Poka, terumbu karang memiliki nilai ekonomi, ketersediaan ikan/biota laut karena adanya terumbu karang, dan adanya pengetahun bahwa pemulihan kondisi terumbu karang merupakan kerja sama masyarakat setempat, pemerintah dan lembaga pendidikan.Kemudian persepsi yang ragu-ragu dan tidak tahu adalah pada indikator manfaat dan kerusakan terumbu karang, dimana pengetahuan yang masih kurang tentang rmanfaat terumbu karang bagi wisata bawah laut/spot diving, kerusakan terumbu karang diakibatkan oleh kerusakan mangrove, penggunaan jangkar perahu nelayan, penambangan batu/karang di perairan laut, penambangan pasir pantai/pasir dari laut, dan sedimentasi.

Hasil obervasi dan wawancara secara mendalam terungkap bahwa memang sebagian responden yang belum memahami manfaat terumbu karang sebagai wisata bawah laut, dan telah terjadi praktek (bukan lagi sebatas persepsi namun perilaku negatif pemanfaatan sumber 
daya)degradasi sumber daya pesisir dan laut di Desa Poka termasuk ekosistem mangrove di sebagian wilayah akibat aktifitas pembangunan perumahan setelah kembalinya penduduk ke Desa Poka akibat konflik sosial di Kota Ambon (sekitar tahun 2005) yang menggunakan material pasir, batu, karang dari pantai dan laut di perairan Desa Poka. Selain itu pembukaan lahan atas yang terus terjadi hingga saat ini untuk pembangunan infrastrukturdi Desa Poka berdampak pada proses sedimentasi yang terus terjadi. Menurut Ohello (2010), pembukaan lahan di daerah pegunungan yang mengakibatkan proses sedimentasi sehingga terjadi kerusakan ekosistem di perairan TAD (Teluk Ambon Dalam) merupakan kondisi yang buruk bagi peairan Teluk Ambon (termasuk perairan laut Desa Poka) pada musim penghujan.

\subsection{Hubungan Persepsi dan WTP Masyarakat}

Sebagian besar persepsi masyarakat di Desa Poka sangat tahu dan tahu merupakan modal dalam perbaikan kerusakan terumbu Karang di Desa Poka. Terkait dengan dana masyarakat untuk perbaikan kerusakan terumbu karang, makaperlu dikatahui kesedian membayar masyarakat di Desa Poka (willingness to pay atau WTP) melalui analisis valuasi ekonomi.Data hubungan antara persepsi dan kesediaan membayar masyarakat terlihat pada Tabel 4 .

Tabel 4. Hubungan Persepsi dan WTP

\begin{tabular}{clrrrrrrr}
\hline \hline \multicolumn{1}{c}{ Uraian } & STT & TT & RR & \multicolumn{1}{c}{ T } & \multicolumn{1}{c}{ ST } & \multirow{2}{*}{ Jumlah } \\
\hline Kesediaan & Bersedia & 0 & 4 & 19 & 47 & 21 & 91 \\
Membayar & Tidak & 0 & 7 & 5 & 3 & 1 & 16 \\
\begin{tabular}{c} 
(WTP) \\
\multicolumn{1}{c}{ Jumlah }
\end{tabular} & 0 & 11 & 24 & 50 & 24 & 107 \\
\hline
\end{tabular}

Berdasarkan data pada Tabel 4, analisis chi-squarehitung adalah 26,178 dan chi-square tabel adalah 9,488, maka chi-square hitung >chisquare tabel, sehingga keputusan untuk menolak $\mathrm{H}_{0}$ atau menerima $\mathrm{H}_{1}$, yakni terdapat hubungan persepsi dan kesediaan membayar masyarakat. Terlihat dengan jelas pada Tabel 4, semakin baik persepsi masyarakat (sangat tahu) semakin tinggi kesediaan membayar masyarakat (dari 11 hingga 24 responden) dan jumlah masyarakat yang tidak bersedia semakin berkurang (dari 7 hingga 1 responden. Dengan demikian peningkatan persepsi masyarakat akan meningkatkan jumlah masyarakat yang bersedia untuk membayar guna perbaikan kerusakan terumbu karang di Desa Poka. Hal ini menurut Nugraha $d k k$ (2018) karena persepsi merupakan faktor pendukung terwujudnya tindakan seseorang.

\subsection{Valuasi Ekonomi}

Valuasi (penilaian) ekonomi kerusakan terumbu karang di Desa Poka, Kota Ambon, diawali dengan perhitungan nilai rataan $W T P$
(EWTP).Dua metode non-parametrik mengandalkan distribusi jawaban "tidak" dan "ya" untuk menghitung EWTP.

Tabel 5. Perhitungan EWTP Metode Trunbull

\begin{tabular}{rrrrrr}
\hline \hline $\begin{array}{c}\text { Lelang } \\
(\mathrm{Bj}) \mathrm{Rp}\end{array}$ & $\begin{array}{c}\text { Jumlah } \\
\mathrm{Nj}\end{array}$ & $\begin{array}{c}\text { Total } \\
(\mathrm{Tj})\end{array}$ & $\begin{array}{c}\text { Distribusi } \\
\text { Tidak (Fj) }\end{array}$ & $\begin{array}{c}\mathrm{F}_{\mathrm{j}}{ }^{*}= \\
\mathrm{F}_{\mathrm{j}+1}-\mathrm{Fj}\end{array}$ & $\begin{array}{c}\text { Nilai } \\
\text { Trunbull }\end{array}$ \\
\hline 2.000 & 3 & 20 & 0.15 & - & \\
5.000 & 3 & 21 & 0.14 & $-0,007$ & $-14,28$ \\
7.500 & 3 & 31 & 0.10 & $-0,046$ & $-230,41$ \\
10.000 & 7 & 35 & 0.20 & 0,103 & $-774,19$ \\
$>10.000$ & & & 1 & 0,800 & $8.000,0$ \\
& & EWTP & & & $8.529,5$ \\
\hline
\end{tabular}

Keterangan: $\mathrm{Nj}$ = responden jawaban "tidak".

Responden menjawab "tidak" atau yang tidak bersedia membayar berjumlah 16 atau $14,95 \%$ responden dan responden menjawab "ya" atau yang bersedia membayar berjumlah 91 atau 85,05\% responden.Pada Tabel 3 dan Tabel 4 menunjukkan bahwa, semakin tinggi nilai bid maka jumlah responden yang menjawab "tidak" atau tidak bersedia membayar relatif meningkatdan responden yang menjawab "ya" atau bersedia membayar relatif menurun (dari 3 dan 17 responden pada bid Rp 2.000,- hingga 7 dan 13 responden pada bid $\mathrm{Rp}$ 10.000,-).Hasil wawancara menunjukkan bahwa responden menganggap nilai bid Rp 2.000,-/bulan dan Rp 5.000,-/bulan terlalu rendah sehingga sebagian besar responden bersedia membayar juga pada nilai bid Rp 7.500,-/bulan dan Rp 10.000,-/bulan, bahkan ada yang bersedia membayar lebih dari Rp 10.000,-/bulan.

Tabel 6. Perhitungan EWTP Metode K-M-T

\begin{tabular}{rrrrrr}
\hline $\begin{array}{c}\text { Lelang } \\
(\mathrm{Bj}) \mathrm{Rp}\end{array}$ & $\begin{array}{c}\text { Jumlah } \\
\mathrm{Nj}\end{array}$ & $\begin{array}{c}\text { Total } \\
(\mathrm{Tj})\end{array}$ & Share & $\left(F j-F_{j+1}\right)$ & \multicolumn{1}{c}{$\begin{array}{c}\text { Nilai } \\
\text { K-M-T }\end{array}$} \\
\hline- & & & 1 & 0,150 & - \\
2.000 & 17 & 20 & 0,85 & $-0,007$ & $-14,28$ \\
5.000 & 17 & 21 & 0,86 & $-0,046$ & $-230,41$ \\
7.500 & 17 & 31 & 0,90 & 0,103 & 774,19 \\
10.000 & 13 & 35 & 0,80 & 0,800 & $8.000,00$ \\
15.000 & & & 0 & & 0,00 \\
& & & & $8.529,49$ \\
\hline
\end{tabular}

Keterangan: $\mathrm{Nj}$ = responden jawaban "ya".

Pada Tabel 5 dan 6nilai rataan willingness to pay/WTP (kesediaan membayar) responden yang bersedia/tidak bersedia adalah sama pada angka $8.529,49$. Hal yang sama juga dihasilkan dalam analisis (contoh perhitungan) yang dikemukakan oleh Fauzi (2014), dimana perhitungan nilai rataan WTP dengan metode Turnbull dan $K-M-T$ menunjukkan angka yang sama pada Rp 12.051,28. Angka sebesar 8.529,49 menunjukkan bahwa rata-rata tiap responden di Desa Poka bersedian membayar Rp 8.529,49/bulan untuk memperbaiki kondisi terumbu karang di Desa Poka.

Nilai dugaan rataan willingness to pay/WTPyang diduga ini kemudian divalidasi menggunakan persamaan yang dikemukakan oleh Haab dan McConnel (2002) dalam Fauzi (2014). Hasil validasi untuk selang kepercayaan 
95\% pada nilai rataan WTPsebesar $\mathrm{Rp}$ $8.529,493 /$ bulan adalah valid atau dapat dipercaya, karena nilai rataan WTPini masuk atau berada dalam nilai batas bawah WTP sebesar Rp 7.838,83/bulan hingga batas atas Rp 9.220,16, atau masuk dalam nilai validasi (Rp 7.838,83/bulan hingga Rp 9.220,16/bulan).

Tabel 7. Nilai Ekonomi Kerusakan Terumbu Karang

\begin{tabular}{cccc}
\hline \hline \multirow{2}{*}{$\begin{array}{c}\text { Nilai rataan } \\
\text { WTP }\end{array}$} & Jumlah & \multicolumn{2}{c}{$\begin{array}{c}\text { Nilai Ekonomi Kerusakan } \\
\text { Terumbu Karang }\end{array}$} \\
\cline { 3 - 4 }$(\mathrm{Rp} /$ bulan $)$ & $\begin{array}{c}\text { Populasi } \\
(\mathrm{KK})\end{array}$ & $\mathrm{Rp} /$ Bulan & $\mathrm{Rp} /$ Tahun \\
\hline $8.529,49$ & 536 & $4.571 .808,29$ & $54.861 .699,54$ \\
\hline
\end{tabular}

Berdasarkan nilai rataan WTP yang telah divalidasi sebesar Rp 8.529,49/bulan kemudian dihitung nilai total WTP (TWTP) sebagai nilai ekonomi kerusakan terumbu karang di Desa Poka. Menurut Fauzi (2010), tahap terakhir dalam teknik CVM adalah mengagregatkan rataan lelang yang diperoleh pada tahap tiga. Proses ini melibatkan konversi data rataan sampel ke rataan populasi secara keseluruhan. Salah satu cara untuk mengkonversi ini adalah mengalikan rataan sampel dengan jumlah rumah tangga (KK) dalam populasi (N). Sehingga diperoleh nilai ekonomi kerusakan terumbu karang di Desa Poka sebesar Rp 4.571.808,29/bulan atau Rp $54.861 .699,54 /$ tahun (Tabel 7). Besarnya nilai ini sekaligus merupakan biaya yang harus dikeluarkan/dikorbankan guna perbaikan terumbu karang di Desa Poka, Kota Ambon.

\subsection{Estimasi Dana Masyarakat}

Estimasi dana masyarakat dalam menunjang upaya dan program perbaikan terumbu karang di Desa Poka dilakukan berdasarkan nilai ekonomi kerusakan sebesar Rp 4.571.808,29/bulan atau Rp 54.861.699,54/tahun. Nilai ini mengartikan bahwa, jika seluruh populasi (dalam penelitian berjumlah $536 \mathrm{KK}$ ) bersedia membayar Rp 8.529,49/bulan untuk memperbaiki kondisi kerusakan terumbu karang di Desa Poka maka terdapat dana masyarakat sebesar Rp 4.571.808,29/bulan atau Rp 54.861.699,54/tahun. Namun dengan pertimbangan bahwa responden yang bersedia membayar hanya sebesar 85,05\% dari sampel, maka jumlah populasi yang bersedia adalah 456 KK, sehingga dana masyarakat yang dapat diperoleh adalah $\mathrm{Rp} 3.888 .322,95 /$ bulan atau $\mathrm{Rp}$ 46.659.875,46/tahun.

Dana ini dapat dikelola oleh Lembaga Pengelola Pesisir (LPP) sebagai lembaga masyarakat di Desa Poka yang dibentuk pada tahun 2007 untuk mengelola sumber daya pesisir dan laut (Yayasan Masnait dan PTD Provinsi Maluku, 2007), bekerja sama dengan Pemerintah Desa Poka atau pemerintah daerah (Kota Ambon atau Provinsi Maluku) sesuai amanat Peraturan Daerah Provinsi Maluku Nomor 10 Tahun 2014 tentang Pengelolaan Ekosistem Terumbu Karang, dimana pada pasal 14 ayat 2 dan 3 bahwa pendanaan pengelolaan ekosistem terumbu karang salah satunya ditunjukkan untuk membiayai pemulihan ekosistem terumbu karang, kemudian dana untuk kegiatan salah satunya dapat bersumber dari swadaya masyarakat (PPM, 2014).Kesediaan masyarakat di Desa Poka untuk berswadaya paling tidak akan mengatasi kelemahan dalam pengelolaan terumbu karang salah satunya menurut Adi $d k k$ (2017) adalah ketergantungan pendanaan dari luar dan keterbatasan pendanaan. Sehingga perbaikan kerusakan terumbu karang di DesaPoka dapat dilakukan secara kontinu dan berdampak pada kesejahteraan masyarakat. Menurut Maulana $d k k$ (2016) upaya perlindungan dan pelestarian ekosistem perairan khususnya ekosistem terumbu karang dapat mendukung kesejahteraan masyarakat.

\section{Kesimpulan}

Disimpulkan bahwa:

1. Persepsi Sebagian besar $(67,29 \%)$ masyarakat terhadap keberadaan terumbu karang di Desa Poka adalahsangat tahu dan tahu, dan hanya sebagian kecil $(32,71 \%)$ masyarakat memiliki persepsi ragu-ragu dan tidak tahu.

2. Terdapat hubungan antara persepsi dan keinginan membayar masyarakat untuk perbaikan kerusakan terumbu karang di Desa Poka.

3. Nilai ekonomi kerusakan terumbu karang di Desa Pokaadalah Rp 4.571.808,29/bulan atau Rp 54.861.699,54/tahun.

4. Estimasi dana masyarakat untuk perbaikan kerusakan terumbu karang di Desa Poka adalah $\mathrm{Rp} 3.888 .322,95 /$ bulan atau $\mathrm{Rp}$ 46.659.875,46/tahun.

\section{DAFTAR PUSTAKA}

Adi, N.D., A. Damar, L. Adrianto, D. Sudarman, dan A. Solihin, 2017. Strategi Pengelolaan Terumbu Karang di Kepulauan Seribu. Jurnal Pengelolaan Sumberdaya Alam dan Lingkungan 7 (3), pp245250.

Adrianto, L., Mujio, dan Y. Wahyudin, 2004. Modul Pengenalan Konsep dan Metodologi Valuasi Ekonomi Sumberdaya Pesisir dan Laut. PKSLPIPB, Bogor.

Akdon dan Ridwan, 2013. Rumus dan Data dalam Aplikasi Statsitika. Albeta, Bandung.

Carson, R.T., R. C. Mitchell, M. Hanemann, R.J. Kopp, S. Presser, P.A. Ruud, 2003. Contingent Valuation and Lost Passive Use: Damage from the Exxon Valdez Oil Spill. Environmental adn Resourse Economics 25: 257-286.

COREMAP (Coral Reef Rehabilitation and Management Program). 2001. Naskah Kebijakan Nasilnal Pengelolaan Terumbu Karang di Indonesia. PMOCOREMAP, Jakarta.

Fauzi, A., 2001. Prinsip-Prinsip Penelitian Sosial Ekonomi Jurusan Sosial Ekonomi Perikanan dan Kelautan. Institut Pertanian Bogor, Bogor. 
Fauzi, A., 2010. Ekonomi Sumberdaya Alam dan Lingkungan. Teori dan Aplikasi. PT. Gramedia Pustaka Utama. Jakarta.

Fauzi, A., 2014. Valuasi Ekonomi dan Penilaian Kerusakan SDA dan Lingkungan. IPB Press, Bogor.

Giyanto, M. Abrar, T. A. Hadi, A. Budiyono, M. Hafizt, A. Salatalohy, dan M. Y. Iswari. 2017. Status Terumbu Karang Indonesia 2017. COREMAP-CTI dan Pusat Penelitian Oseanografi - LIPI, Jakarta.

Hiariey, L. S., 2013. Peran Serta Masyarakat Pemanfaat Pesisir Dalam Pengelolaan Wilayah Pesisir Teluk Ambon dalam. Jurnal Matematika, Sains, dan Teknologi 14 (1), pp 48-61.

Indrabudi, T., dan R. Alik, 2017. Status Kondisi Terumbu Karang du Teluk Ambon. Widyariset 3 (1), pp 81-94.

[LIPI] Lembaga Ilmu Pengetahuan Indonesia, 2015. Kondisi Terumbu Karang di Perairan Teluk Ambon, Pulau Ambon Tahun 2015. Laporan Tahunan Lembaga Ilmu Pengetahuan Indonesia Ambon, Ambon.

Nazir, M.,2014. Metode Penelitian, Salemba Empat (Cetakan ke-9), Jakarta.

Nugraha, A. S., H. Sutjahjo, dan A.Amin, 2018. Persepsi dan Partisipasi Masyarakat Terhadap Pengelolaan Sampah Rumah Tangga Melalui Bank Sampah di Jakarta Selatan. Jurnal Pengelolaan Sumberdaya Alam dan Lingkungan 8 (1), pp 1-14.

Maulana, H., Anggoro, S., Yulianto, B. 2016. Kajian Kondisi dan Nilai Ekonomi Manfaat Ekosistem Terumbu Karang di Pantai Wediombo, Kabupaten Gunung Kidul, Daerah Istimewa Yogyakarta. Jurnal Ilmu Lingkungan,14(2),82-87, doi:10.14710/jil.14.2.82-87.

Ohello, M. T., 2010. Kondisi Lingkungan Perairan Teluk Ambon Dalam dan Hubungannya Dengan Perilaku Masyarakat. Tesis Pascasarjana Program Studi Pengelolaan Sumberdaya Alam dan Lingkungan Institut Pertanian Bogor, Bogor.
Pelasula, D. D., 2017. Degradasi Terumbu Karang Teluk Ambon dan Upaya Rehabilitasi. Pusat Penelitian Laut dalam LIPI, Ambon.

[PKA] Pemerintah Kota Ambon, 2013. Peraturan Daerah Kota Ambon Nomor 5 Tahun 2013 Tentang Retribusi Pelayanan Persampahan/Kebersihan. Lembaran Daerah Kota Ambon Tahun 2012 Nomor 5, Ambon.

[PPM] Pemerintah ProvinsiMaluku, 2014. Peraturan Daerah Provinsi Maluku Nomor 10 Tahun 2014 Tentang Pengelolaan Ekosistem Terumbu Karang. Lembaran Daerah Provinsi Maluku Tahun 2014 Nomor 10, Ambon.

Ralahalu, K. A., 2012. Berlayar dalam Ombak, Berkarya Bagi Negeri: Pemikiran Anak negeri untuk Maluku. Ralahalu Institut, Maluku.

Rakhmat, J., 2007. Persepsi dalam Proses Belajar Mengajar. Rajawali Press, Jakarta.

Sahetapy, D., S. Widayati dan M. Sangadji, 2017. Dampak Aktivitas Masyarakat Terhadap Ekosistem Terumbu Karang di Perairan Pesisir Dusun Katapang Kabupaten Seram Bagian Barat. Jurnal TRITON 13 (2), pp 105-114.

Sugiyono,2011. Metode Penelitian Kuantitatif Kualitatif dan R dan D. Alfabeta, Bandung.

Sugiyono, 2015. Statistika Nonparametris Untuk Penelitian. Alfabeta, Bandung.

Sujarweni, V. W., 2015. Metodologi Penelitian Bisnis dan Ekonomi. Pustaka Baru Press, Yogyakarta.

Yayasan Masnait dan PTD Provinsi Maluku, 2007. Dokumen Kesepakatan Para Raja, Kepala Desa, Lurah Dan Kewang Empat Belas (14) Negeri/Desa/Kelurahan Pada Kecamatan Teluk Ambon Baguala, Teluk Ambon, Dan Kecamatan Leitimur Selatan Tentang Pengelolaan Ekosistem Mangrove Dengan Pendekatan Sasi. Yayasan Masnait dan Peace Throught Development Provinsi Maluku, Ambon. 